TABLE. Relative reduction rates of hexacyanoferrate(III) under different conditions

Methylene Blue
$10^{-5} \mathrm{M}$
$4 \cdot 0$
$2 \cdot 4$
$1 \cdot 2$
0
$1 \cdot 2$
$1 \cdot 2$

$\mathrm{FeCl}_{2} / \mathrm{M}$
0.01
0.01
0.01
0.01
0
0.01

Lighta
+
+
+
+
+
+

Relative
rates
$4 \cdot 0$
$2 \cdot 5$
$1 \cdot 0$
0
0
0

a + Irradiated, - non-irradiated.

either hexacyanoferrate(III), iron(II) chloride or light no reduction was observed. The reduction rate was found to increase linearly with Methylene Blue concentration. Neither hexacyanoferrate(III) nor iron(II) chloride penetrated the phospholipid wall. Self reduction of Methylene Blue and hexacyanoferrate(III) does not occur, as described previously. From these results, it is clear that hexacyanoferrate(III) is an electron acceptor and iron(II) chloride is an electron donor. The reaction is thought to proceed via steps (1)-(4).

$$
\begin{aligned}
& \mathrm{MB}(\text { out })+h \nu \rightarrow \mathrm{MB}^{*}(\text { out }) \\
& \mathrm{MB}^{*}(\text { out })+\mathrm{Fe}^{2+} \rightarrow \mathrm{LMB}(\text { out })+\mathrm{Fe}^{3+}
\end{aligned}
$$

$$
\begin{aligned}
& \text { LMB(out) } \rightarrow \text { LMB(in) } \\
& \text { LMB(in) }+ \text { hexacyanoferrate }(\mathrm{III}) \rightarrow \mathrm{MB}+ \\
& \text { hexacyanoferrate(II) }
\end{aligned}
$$

where $\mathrm{MB}=$ Methylene Blue, LMB = leuco Methylene Blue, out $=$ outside, in $=$ inside.

This electron transfer does not occur under ordinary conditions for the following reasons. First, the redox potential of iron(II) chloride $\left(E_{0}^{\prime} 0.77 \mathrm{~V}\right)$ is higher than that of hexacyanoferrate(III) $\left(E_{0}^{\prime} 0.33 \mathrm{~V}\right)$. Secondly, iron(II) chloride reacts rapidly with potassium hexacyanoferrate(III) to form a deep blue precipitate of iron(II) hexacyanoferrate(III) (Turnbull's Blue). When the vesicle containing potassium hexacyanoferrate(III) inside and iron(II) chloride outside was destroyed by the addition of detergent, the dispersion soon turned deep blue and Turnbull's Blue was precipitated.

Thus we have carried out a photosensitized reduction of hexacyanoferrate(III) by iron(II) chloride in the liposome system. This reaction is noteworthy because it cannot be observed in the ordinary system.

(Received, 19th June 1979; Com. 654.)

${ }^{1}$ M. Mangel, Biochim. Biophys. Acta, 1976, 430, 459.

2 Y. Toyoshima, M. Morino, H. Motoki, and M. Sukigara, Nature, 1977, 265, 187.

3 J. W. Otvos and M. Calvin, Nature, 1978, 274, 507; Internat. J. Energy Res., 1979, 3, 80.

4 M. Mangel, D. Bevns, and A. Ilani, J. Membrane Biol., 1975, 20, 171.

5 H. Ti. Tien and S. P. Verna, Nature, 1969, 227, 1232.

${ }^{6} \mathrm{Y}$. Sudo and F. Toda, Natuve, 1979, 279, 807.

7 C. H. Lea, D. H. Rhodes, and R. D. Stoll, Biochemistry, 1975, 60, 353.

\title{
Intramolecular Rearrangements of Sulphines Co-ordinated to Pt Involving Insertion and Reductive Coupling Reactions. $X$-Ray Crystal and Molecular Structure of $(E)-\left[\mathrm{Pt}^{\mathrm{II}}(\mathrm{PhS})\left(\mathrm{PPh}_{3}\right)_{2}(\mathrm{PhSCSO})\right] \cdot \mathrm{C}_{6} \mathrm{H}_{6}$, a New Type of Heterocumulene-Metal Complex $\dagger$
}

\author{
By Johan W. Gosselink, ${ }^{a}$ Anja M. F. Brouwers, ${ }^{b}$ Gerard van Koten, ${ }^{* a}$ and Kees Vriezea \\ ( a Anorganisch Chemisch Laboratorium and b Laboratorium voor Kristallografie, J. H. van 't Hoff Instituut, \\ University of Amsterdam, Niewwe Achtergracht 166, 1018 WV Amsterdam, The Netherlands)
}

Summary The $\mathrm{Pt}^{0}\left(\mathrm{PPh}_{3}\right)_{2}$-unit in $\left[\mathrm{Pt}^{0}\left(\mathrm{PPh}_{3}\right)_{2}(\mathrm{XYCSO})\right]$ $(\mathrm{X}=\mathrm{Y}=S$-aryl or $\mathrm{X}=S$-alkyl, $\mathrm{Y}=$ aryl, both stereoisomers), in which the sulphine XYCSO is $\eta^{2}$-CS co-ordinated, inserts into a $\mathrm{C}-\mathrm{S}$ bond yielding an equilibrium mixture consisting of two stereoisomers $(E)$ and $(Z)$-[PtIIX $\left.\left(\mathrm{PPh}_{3}\right)_{2}(\mathrm{YCSO})\right]$ and varying amounts of $\left[\mathrm{Pt}\left(\mathrm{PPh}_{3}\right)_{2}(\mathrm{XYCSO})\right]$, depending on the geometry of the co-ordinated sulphine.

Sulphines (XYCSO) are heterocumulenic systems, which, in principle, can co-ordinate to metal centres via the CSOunit in a variety of ways, i.e., via $\eta^{1-S}, \eta^{1-O}, \eta^{2}-\mathrm{CS}$, or
$\eta^{2}$-SO. Moreover, when $\mathrm{X}$ and $\mathrm{Y}$ are non-equivalent the planar bent sulphine molecule $\mathrm{e}^{1,2}$ exists as two stereoisomers, thus resulting in two metal-sulphine stereoisomers on complexation $\left\{c f\right.$., $\left[\mathrm{Pt}\left(\mathrm{PPh}_{3}\right)_{2}\left\{\left(\mathrm{p}-\mathrm{MeC}_{6} \mathrm{H}_{4}\right)(\mathrm{MeS}) \mathrm{CSO}\right\}\right],{ }^{3}$ and $\left[\mathrm{Fe}(\mathrm{CO})_{3}\left(\mathrm{H}_{2} \mathrm{C}=\mathrm{CHCH}=\mathrm{S}=\mathrm{O}\right)\right]^{4}{ }^{4}$ which contain $\eta^{2}$-CS co-ordinated XYCSO , When $\mathrm{X}, \mathrm{Y}=S$-aryl, $S$-alkyl, or $\mathrm{Cl}$, in addition to co-ordination, insertion of the metal centre into the $\mathrm{C}-\mathrm{X}$ or $\mathrm{C}-\mathrm{Y}$ bond might also take place.

We now report the co-ordination behaviour of XYCSO to $\mathrm{Pt}^{0}$. We shall concentrate on intramolecular rearrangement processes of co-ordinated sulphine involving $\mathrm{C}-\mathrm{S}$ bond breaking and bond formation.

† Throughout this article, $(E)$ and $(Z)$ refer to the configuration of the sulphine $\mathrm{C}=\mathrm{S}$ bond. If these are placed inside the molecular formula, this indicates that the sulphine has the $(E)$ or $(Z)$ configuration, and is co-ordinated as such $\left(\eta^{2}\right)$ through the $\mathrm{C}=\mathrm{S}$ bond. If these are placed outside the molecular formula, this indicates that the $\mathrm{Pt}(\mathrm{PhS}) \mathrm{C}=\mathrm{S}=\mathrm{O}$ co-ordinated entity as a whole has the $(E)$ or $(Z)$ configuration, co-ordination being through a $\mathrm{Pt}-\mathrm{C} \sigma$-bond. 
<smiles>O=S=C(c1ccccc1)P(=P)(c1ccccc1)c1ccccc1</smiles>

$(E)-(3 b)$

The sulphines $(\mathbf{1} \mathbf{a}-\mathbf{e})$ react with $\left[\mathrm{Pt}^{0}\left(\mathrm{PPh}_{3}\right)_{4}\right]$ to form (2a-e) (see Scheme), containing $\eta^{2}$-CS co-ordinated XYCSO. Separate reactions with the stereoisomers $(\mathbf{1 d})$ or (1e) yield the corresponding isomeric complexes (2d) or (2e), indicating that the configuration of the sulphine is retained upon co-ordination to $\mathrm{Pt}^{0}{ }^{3}$ In the absence of reactive side-bonds, $c f$. (1a), the corresponding co-ordination compound $(\mathbf{2} \mathbf{a})$ remains stable in solution at room temperature. In contrast the $\mathrm{Pt}^{0}\left(\mathrm{PPh}_{3}\right)_{2}$-unit in $(\mathbf{2} \mathbf{b}, \mathbf{c})(\mathrm{X}=\mathrm{Y}=$ $S$-aryl) inserts intramolecularly and irreversibly in solution $\left(25^{\circ} \mathrm{C}\right.$, in $\left.c a .24 \mathrm{~h}\right)$ into one of the $\mathrm{C}-\mathrm{S}$ bonds, yielding two isomeric insertion products $(E)$ - and $(Z)-(\mathbf{3 b}, \mathbf{c})$ (see Scheme).

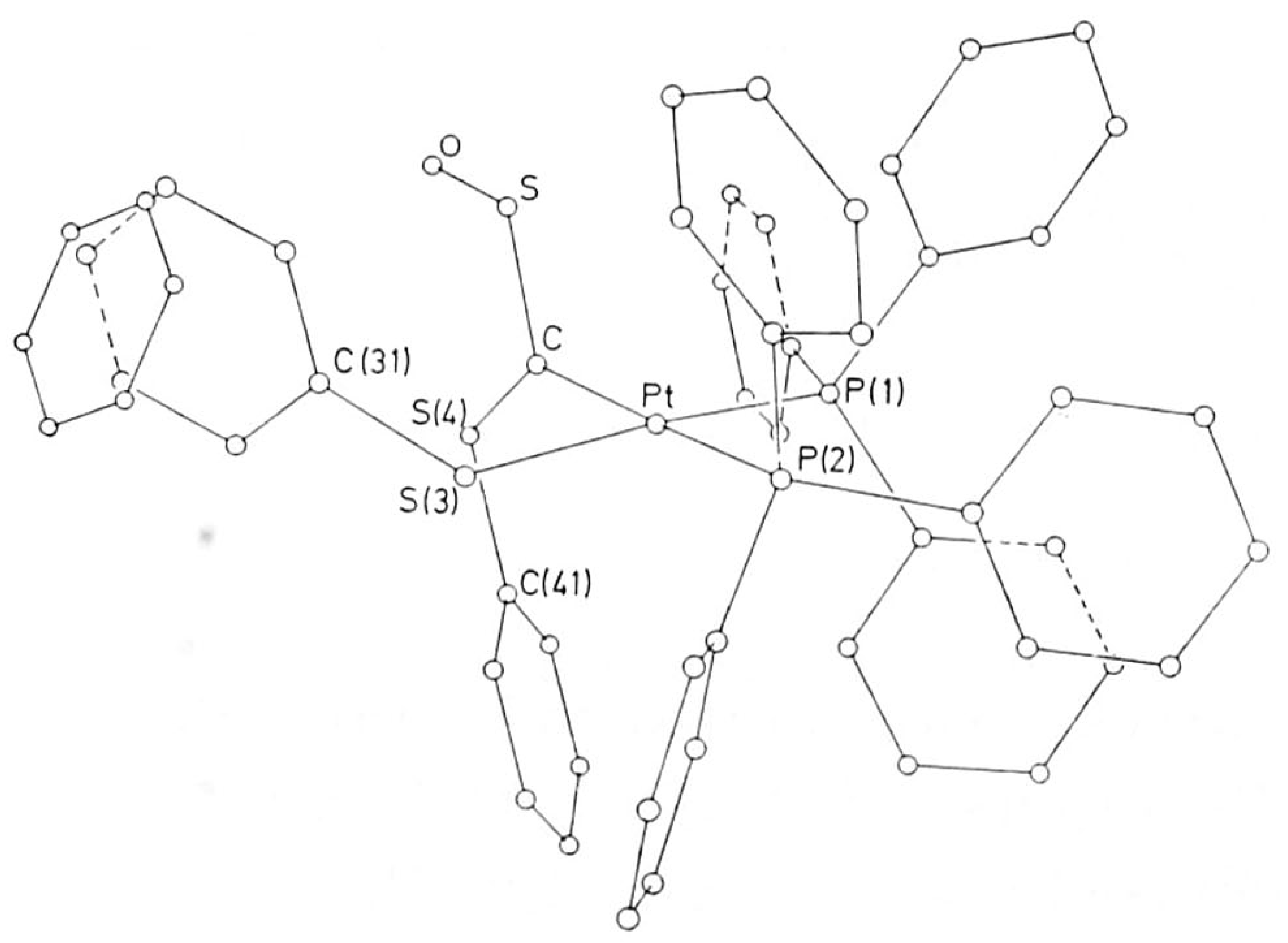

FIGURE. ORTEP drawing of the molecular structure of $(E)-\left(3 \mathbf{b}^{\prime}\right.$ Important bond angles and distances are: $\mathrm{Pt}-\mathrm{C}, 2 \cdot 01(1)$; $\mathrm{Pt}-\mathrm{P}(1)$, $2 \cdot 336(4)$; Pt-P(2), $2 \cdot 287(3)$; Pt-S(3), $2 \cdot 379(4)$; C-S, $1 \cdot 65(1)$; $\mathrm{S}-\mathrm{O}, 1 \cdot 50(2) ; \mathrm{C}-\mathrm{S}(4), 1 \cdot 73(1) \AA ;<\mathrm{P}(1)-\mathrm{Pt}-\mathrm{S}(3), 82 \cdot 6(1) ; \mathrm{P}(1)-$ Pt-P(2), $\quad 96 \cdot 8(1) ; \quad \mathrm{P}(2)-\mathrm{Pt}-\mathrm{C}, \quad 89 \cdot 3(4) ; \quad \mathrm{C}-\mathrm{Pt}-\mathrm{S}(3), \quad 91 \cdot 7(4)$; Pt-C-S, $113 \cdot 5(7) ; \quad \mathrm{Pt}-\mathrm{C}-\mathrm{S}(4), \quad 134 \cdot 1(8) ; \mathrm{S}(4)-\mathrm{C}-\mathrm{S}, \quad 112 \cdot 4(8)$; C-S-O, $115 \cdot 7(9) ; \mathrm{C}-\mathrm{S}(4)-\mathrm{C}(41), 107 \cdot 0(5) ; \mathrm{Pt}-\mathrm{S}(3)-\mathrm{C}(31), 111 \cdot 0(2)^{\circ}$.
Compound (E)-(3b) crystallizes preferentially from benzene. A single-crystal $X$-ray structure determination shows that this isomer has the structural formula $(E)$ - $\left[\mathrm{PtII}_{-}\right.$ $\left.(\mathrm{PhS})\left(\mathrm{PPh}_{3}\right)_{2}(\mathrm{PhSCSO})\right] \cdot \mathrm{C}_{6} \mathrm{H}_{6}$ (see Figure). Crystal data: orthorhombic, with cell dimensions $a=10 \cdot 28, b=21 \cdot 44$, $c=21 \cdot 65 \AA, U=4774 \AA^{3}, Z=4$, space group $P 2_{1} 2_{1} 2_{1}$. 4349 independent reflections from a total of 4527 , which were measured on a Nonius CAD-4 diffractometer using $\mathrm{Cu}-K_{\alpha}$ radiation, have been considered as observed $[I>2 \cdot 5 \sigma(I)]$. The final $R$-factor is $0 \cdot 06$.

The Pt-atom lies in the sulphine plane, which is perpendicular to the plane through $\mathrm{P}(1) \mathrm{PtP}(2)$ and is situated anti with respect to the $\mathrm{O}$-atom. The $\mathrm{PhSCSO}$-fragment has the same $s$-cis configuration in both $(E)-(\mathbf{3} \mathbf{b})$ and the free sulphine $(Z)-\left(2,4,6-\mathrm{Me}_{3} \mathrm{C}_{6} \mathrm{H}_{2}\right)(\mathrm{PhS}) \mathrm{CSO}^{5}$ On the basis of this observation and by analogy with the stereoisomerism found in the free sulphines (where $\mathrm{X} \neq \mathrm{Y}$ ), the $\mathrm{O}$ and $\mathrm{Pt}$ atoms in $(Z)-(\mathbf{3} \mathbf{b}) \S$ are thought to be situated syn.

Interestingly, in $(\mathbf{2} \mathbf{b})$ and $(\mathbf{2 e})$ the $\mathrm{Pt}^{0}\left(\mathrm{PPh}_{3}\right)_{2}$ unit also inserts in the $\mathrm{C}-\mathrm{S}$ bond, yielding, irrespective of whether $(\mathbf{2 d})$ or $(\mathbf{2 e})$ is used as starting material, a ca. $1: 1: 1$ mixture of $(\mathbf{2} \mathbf{d}),(E)-(\mathbf{3 d})$, and $(Z)-(\mathbf{3 d}) \boldsymbol{q}$ (see Scheme). Surprisingly, only traces of $(\mathbf{2 e})$ are present in the final reaction mixture. ${ }^{31}$ P-N.m.r. spectra recorded on a solution of $(E)-(3 \mathbf{d})$ in $\mathrm{CDCl}_{3}$ showed the initial presence of $(E)$ - and $(Z)-(3 \mathrm{~d})$ in a $1: 1$ molar ratio, whilst, over a period of $c a$. $24 \mathrm{~h}$, (2d) was formed until a $1: 1: 1$ equilibrium was reached. These observations show that the insertion and co-ordination products $[(E)-$ and $(Z)-(3 \mathbf{d})$, and $(\mathbf{2 d})$ and $(\mathbf{2 e})$, respectively] are in equilibrium. Reformation of $(\mathbf{2 d})$ implies that a reductive coupling of $\mathrm{MeS}$ and $p-\mathrm{MeC}_{6} \mathrm{H}_{4} \mathrm{CSO}$ takes place in the insertion products.

The present results indicate the influence of the geometry of the sulphine ligand and $\mathrm{Pt}-\mathrm{CSO}$ fragment on the thermodynamic stability of the complexes. This is clearly illustrated by the absence of the specific co-ordination product, $\left[\mathrm{Pt}^{0}\left(\mathrm{PPh}_{3}\right)_{2}\left\{(Z)-\left(p-\mathrm{MeC}_{6} \mathrm{H}_{4}\right)(\mathrm{MeS}) \mathrm{CSO}\right\}\right](\mathbf{2 e})$ in the equilibrium mixture, which contains $\left[\mathrm{Pt}^{0}\left(\mathrm{PPh}_{3}\right)_{2}\{(E)-(p-\mathrm{Me}-\right.$ $\left.\left.\left.\mathrm{C}_{6} \mathrm{H}_{4}\right)(\mathrm{MeS}) \mathrm{CSO}\right\}\right](\mathbf{2 d})$, and $(E)$ - and $(Z)-\left[\mathrm{PtII}(\mathrm{MeS})\left(\mathrm{PPh}_{3}\right)_{2^{-}}\right.$ $\left.\left(p-\mathrm{MeC}_{6} \mathrm{H}_{4} \mathrm{CSO}\right)\right](E)-$ and $(Z)-(\mathbf{3 d})$, and by the quantitative formation of the insertion products $(E)$ - and $(Z)-[\mathrm{PtII}(\mathrm{RS})-$ $\left.\left(\mathrm{PPh}_{3}\right)_{2}(\mathrm{RSCSO})\right](E)-$ and $(Z)-(\mathbf{3} \mathbf{b}, \mathbf{c})$ from $\left[\mathrm{Pt}^{0}\left(\mathrm{PPh}_{3}\right)_{2^{-}}\right.$ $\left.\left\{(\mathrm{RS})_{2} \mathrm{CSO}\right\}\right](\mathbf{2} \mathbf{b}, \mathbf{c})$. In these co-ordination products $(\mathbf{2} \mathbf{b}, \mathbf{c}, \mathbf{e})$ the O-atom is situated $s y n$ to an S-atom.

A detailed study of these systems, which are unique, because both insertion and co-ordination products are present in equilibrium, might provide better insight into

$\ddagger$ All Pt, P, and S atoms have been refined anisotropically; the carbon atoms belonging to phenyl rings have been refined as ideal groups and the $\mathrm{C}$ and $\mathrm{O}$ atoms of the CSO-fragment have been refined isotropically. The refinement has been carried out by means of a block diagonal least-square programme, using a Cruickshank weighting scheme. No attempt has been made to localize the H-atoms. The atomic co-ordinates for this work are available on request from the Director of the Cambridge Crystallographic Data Centre, University Chemical Laboratory, Lensfield Road, Cambridge CB2 1EW. Any request should be accompanied by the full literature citation for this communication.

$\S{ }^{31} \mathrm{P}-\mathrm{N} . \mathrm{m} . \mathrm{r}$. data of the insertion products are $(E)-(3 \mathbf{b}):{ }^{1} J\left(\mathrm{Pt}-\mathrm{P}_{\mathrm{c}}\right) 2448 \mathrm{~Hz},{ }^{1} J\left(\mathrm{Pt}-\mathrm{P}_{\mathrm{s}}\right) 2985 \mathrm{~Hz}$, and $(Z)-(3 \mathbf{b}):{ }^{1} J(\mathrm{Pt}-\mathrm{P} \mathrm{c}) 2296 \mathrm{~Hz}$ and ${ }^{1} J\left(\mathrm{Pt}-\mathrm{P}_{\mathrm{s}}\right) 3073 \mathrm{~Hz}\left(\mathrm{P}_{\mathrm{c}}\right.$ and $\mathrm{P}_{\mathrm{s}}$, respectively $\mathrm{P}$ trans to $\mathrm{C}$ and $\mathrm{P}$ trans to $\left.\mathrm{S}\right)$. The i.r. spectra (KBr-mulls) of $(E)-$ and $(Z)-(3 \mathrm{~b})$ show different CSO-vibrations: $(E)-(3 \mathrm{~b}) 1079(\mathrm{~s})$ and $950(\mathrm{~s}) \mathrm{cm}^{-1}$ and $(Z)-(3 \mathrm{~b}) 980(\mathrm{~s}) \mathrm{cm}^{-1}$. The ${ }^{1} \mathrm{H}-\mathrm{n}$.m.r. spectra of $(E)-$ and $(Z)$ (3c) show that the Me-group of the $p-\mathrm{MeC}_{6} \mathrm{H}_{4} \mathrm{SCSO}$ fragment in $(E)-(3 \mathbf{c})$ is shifted $0 \cdot 1$ p.p.m. downfield compared to the free ligand. This is due to the fact that this group lies in the deshielding zone of $\mathrm{Pt}{ }^{\mathrm{II}}[c f$. s-cis conformation of $(E)-(\mathbf{3 b} \mathbf{b})]$. The Me-group of the $p-\mathrm{MeC}_{6} \mathrm{H}_{4} \mathrm{~S}-\mathrm{Pt}$-fragment in both $E$ - and $Z-(3 \mathrm{c})$ and of the $p-\mathrm{MeC}_{6} \mathrm{H}_{4} \mathrm{SCSO}$-fragment in $Z-(3 \mathrm{c})$ is shifted $0 \cdot 3$ p.p.m. upfield compared to the free ligand, indicating a gauche conformation for the $p-\mathrm{MeC}_{6} \mathrm{H}_{4} \mathrm{SCSO}-\mathrm{Pt}$-fragment in $(Z)-(3 \mathrm{c})$, as was found for $(E)$ -
$\left(2,4,6-\mathrm{Me}_{3} \mathrm{C}_{6} \mathrm{H}_{2}\right)(\mathrm{PhS}) \mathrm{CSO}$ (ref.5).

Tf ${ }^{31} \mathrm{P}-\mathrm{N} . \mathrm{m} . \mathrm{r}$. data, for $(E)-(\mathbf{3 d})\left[{ }^{1} J\left(\mathrm{Pt}-\mathrm{P}_{\mathrm{c}}\right) 2317 \mathrm{~Hz}\right.$ and $\left.{ }^{1} J\left(\mathrm{Pt}-\mathrm{P}_{\mathbf{s}}\right) 2873 \mathrm{~Hz}\right]$ and $Z$-(3d) $\left[{ }^{1} J\left(\mathrm{Pt}_{-} \mathrm{P}_{\mathrm{c}}\right) 2159 \mathrm{~Hz}\right.$ and $\left.{ }^{1} J(\mathrm{Pt}-\mathrm{P}) 3016 \mathrm{~Hz}\right]$, when compared with those of $(E)$ - and $(Z)-(\mathbf{3 b})$, indicate that these compounds are also insertion products. 


$$
\begin{aligned}
& {\left[\mathrm{Pt}^{\circ}\left(\mathrm{PPh}_{3}\right)_{4}\right]+\mathrm{XYCSO} \longrightarrow\left[\mathrm{Pt}^{\circ}\left(\mathrm{PPh}_{3}\right)_{2}(\mathrm{XYCSO})\right]+2 \mathrm{PPh}_{3}} \\
& (1 a-e) \quad(2 a-e)
\end{aligned}
$$

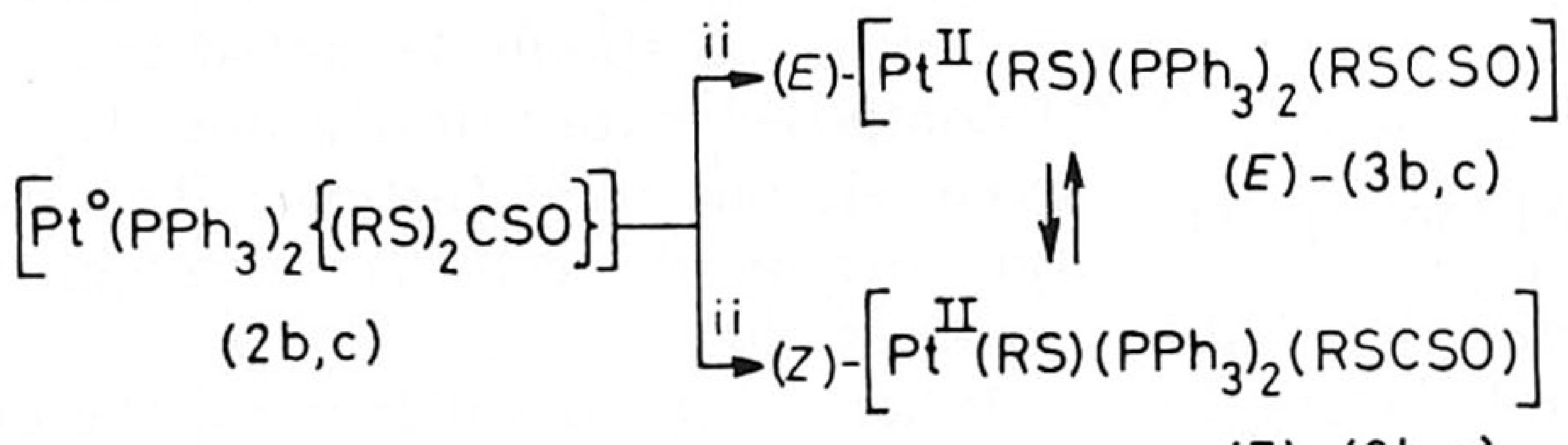

$$
\begin{aligned}
& (z)-(3 b, c)
\end{aligned}
$$

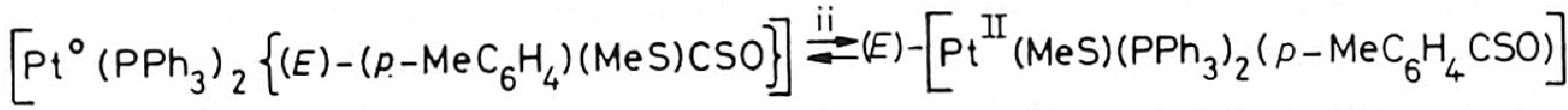

$$
\begin{aligned}
& 14 \quad(E)-(3 d) \\
& {\left[\mathrm{Pt}^{\circ}\left(\mathrm{PPh}_{3}\right)_{2}\left\{(z)-\left(p-\mathrm{MeC}_{6} \mathrm{H}_{4}\right)(\mathrm{MeS}) \mathrm{CSO}\right\}\right] \underset{\rightarrow}{\mathrm{ii}} \rightarrow(Z)-\left[\mathrm{Pt}^{\mathrm{II}}(\mathrm{MeS})\left(\mathrm{PPh}_{3}\right)_{2}\left(p-\mathrm{MeC}_{6} \mathrm{H}_{4} \mathrm{CSO}\right)\right]}
\end{aligned}
$$

$$
\begin{gathered}
\text { a; } \mathrm{X}, \mathrm{Y}=\text { fluoren-9-ylidene } \\
\text { b; } \mathrm{X}=\mathrm{Y}=\mathrm{PhS} \\
\text { c; } \mathrm{X}=\mathrm{Y}=p \text { - } \mathrm{MeC}_{6} \mathrm{H}_{4} \mathrm{~S} \\
\mathrm{~d} ; \mathrm{X}=\mathrm{MeS}, \mathrm{Y}=p-\mathrm{MeC}_{6} \mathrm{H}_{4}(E \text {-isomer }) \\
\mathrm{e} ; \mathrm{X}=\mathrm{MeS}, \mathrm{Y}=p-\mathrm{MeC}_{6} \mathrm{H}_{4}(Z \text {-isomer }) \\
\text { i, in benzene or toluene; ii, in } \mathrm{CDCl}_{3} \\
\mathrm{R}=\mathrm{Ph} \text { or } p-\mathrm{MeC}_{6} \mathrm{H}_{4} \\
\text { Scheme }
\end{gathered}
$$

the intimate mechanisms involved in oxidative insertion and reductive coupling reactions of heterocumulenes on transition metal centres.**

We thank Prof. B. Zwanenburg and Mr. B. H. M. Lammerink of the Department of Organic Chemistry, University of Nijmegen (The Netherlands), for their assistance and useful comments during the syntheses of the sulphines.

** Preliminary experiments revealed that in trans- $\left[\mathrm{Rh}^{\mathrm{I}} \mathrm{Cl}\left(\mathrm{PCy}_{3}\right)_{2}(\right.$ fluorene-9-ylidene-SO $\left.)\right](\mathrm{Cy}=\mathrm{cyclohexyl})\left[{ }^{1} J(\mathrm{Rh}-\mathrm{P}) 113 \mathrm{~Hz}\right.$, $\delta(\mathrm{P}) 28.8$ p.p.m. (relative to $\left.80 \% \mathrm{H}_{3} \mathrm{PO}_{4}\right), \nu(\mathrm{CSO}) 1118,1090$, and $1022 \mathrm{~cm}^{-1}$ (KBr-mulls) ] the sulphine ligand is $\eta^{1}-\mathrm{S}$ bonded. The reaction of $\left[\left(\mathrm{PCy}_{3}\right)_{2} \mathrm{Rh}^{\mathrm{I} C l}\left(\mathrm{C}_{8} \mathrm{H}_{14}\right)\right]$ with $Z-\left(p-\mathrm{MeC}_{6} \mathrm{H}_{4}\right)(\mathrm{MeS}) \mathrm{CSO}$ afforded $\left[\mathrm{Rh}^{\mathrm{I} C l}\left(\mathrm{PCy}_{3}\right)\left\{(Z)-\left(p-\mathrm{MeC}_{6} \mathrm{H}_{4}\right)(\mathrm{MeS}) \mathrm{CSO}\right\}\right]\left[{ }^{1} J(\mathrm{Rh}-\mathrm{P}) 185 \mathrm{~Hz}\right.$, $\delta$ (P) 51.0 P.m. (relative to $\left.\left.80 \% \mathrm{H}_{3} \mathrm{PO}_{4}\right), \nu(\mathrm{SO}) 1046 \mathrm{~cm}^{-1}(\mathrm{KBr}-\mathrm{mulls}),{ }^{3} J\left(\mathrm{Rh}-\mathrm{SCH}_{3}\right) 3 \mathrm{~Hz}\right]$ instead of insertion products. In this compound the sulphine is probably co-ordinated via the $\mathrm{S}$-atom and the $\mathrm{C}=\mathrm{S}$-fragment.

1 Th W Hummelink, Cryst. Struct. Comm., 1975, 4, 441.

2 R. B. Bates and G. A. Wolfe, J. Amer. Chem. Soc., 1968, 90, 6854.

3 J. W. Gosselink, G. van Koten, K. Vrieze, B. Zwanenburg, and B. H. M. Lammerink, J. Organometallic Chem., 1979, 179, in the press.

${ }^{4}$ D. C. Dittmer, K. Takahashi, M. Iwanami, A. I. Tsai, P. L. Chang, B. B. Bildner, and I. K. Stamos, J. Amer. Chem. Soc., 1973 95, 6113; ibid., 1976, 98, 2795.

5 A. Tangerman and B. Zwanenburg, J.C.S. Perkin II, 1975, 352.

\title{
Production of $\mathrm{H}_{2}$ and $\mathrm{CO}$ from Liquid Water and Carbon using Solar Energy
}

\author{
By Tomoji Kawai and Tadayoshi Sakata \\ (Institute for Molecular Science, Myodaiji, Okazaki, 444, Japan)
}

Summary Gaseous $\mathrm{H}_{2}, \mathrm{CO}$, and $\mathrm{CO}_{2}$ were produced from water and carbon by photocatalytic processes using $\mathrm{TiO}_{2}-\mathrm{RuO}_{2}$ as a catalyst.

THE utilization of solar energy is of importance in view of the energy and raw material crises, and several photocatalytic reactions have been reported. ${ }^{1}$ Coal gasification or liquefaction is also a topic of current interest. We have therefore studied the use of solid carbon (in place of coal or coke) and liquid water as raw materials for the production of gaseous products by a photocatalytic process.
We report here that gaseous $\mathrm{H}_{2}$ and $\mathrm{CO}$ were produced at around room temperature when an aqueous suspension of carbon with $\mathrm{TiO}_{2}-\mathrm{RuO}_{2}$ as catalyst was illuminated.

Typically, $\mathrm{TiO}_{2}(30 \mathrm{mg})$ (Katayama Co.), $\mathrm{RuO}_{2}$ catalyst (10 mg) (Rare Metalic Co.), and active carbon $(0.5 \mathrm{mg})$ (Katayama Co.) were mixed and rubbed in an agate mortar, and suspended in neutral water $(10 \mathrm{ml})$ in a Pyrex cell which was then evacuated. The mixture was illuminated with a $500 \mathrm{~W}$ Xe lamp for $12 \mathrm{~h}$ and the gas evolved was trapped at -197 and $-78{ }^{\circ} \mathrm{C}$, and analysed by mass spectrometry. The gas was not condensed at $-197^{\circ} \mathrm{C}$, 